\title{
PATERNAL INVOLVEMENT, MATERNAL EMPLOYMENT, AND ADOLESCENTS' ACADEMIC ACHIEVEMENT: An 11-Year Follow-Up
}

Edith Williams, M.S.W., and Norma Radin, Ph.D.

An 11-year follow-up study explored the effects of paternal involvement in child rearing and maternal employment in prior years on grades and educational expectations of a group of white, middle-class adolescents from intact families. Past maternal employment was found to be a more powerful predictor of children's academic performance and expectations than was amount of father involvement. Part-time maternal employment appeared to be optimal for children's academic expectations.

$\mathrm{T}$ he long-term effects of maternal employment and father participation in child rearing on children's academic performance are a matter of interest to clinicians, educators, and researchers alike. The present inquiry uses data collected in a longitudinal study originally designed to examine the consequences of fathers' taking major responsibility for their preschool child's care in intact white middle-class families. The paper focuses on the extent to which the academic achievement and expectations of the children $(N=32)$, now teenagers, were affected by the degree to which their fathers participated in child rearing and by their mothers' employment when they were 3-5 and 7-9 years of age.

Research conducted in the past 20 years strongly suggests that greater quantity and better quality of paternal participation are predictors of enhanced academic achieve- ment for children (Gottfried, Gottfried, \& Bathurst, 1988; Hoffman, 1989; Zaslow, Rabinovich, \& Suwalsky, 1991). This is particularly true for sons (Jordan, Radin, \& Epstein, 1975; Radin, 1972, 1981b, 1986; Radin \& Russell, 1983), as they tend to model their powerful but nurturant fathers' behavior and internalize his problemsolving abilities and manner of thinking (Eccles \& Hoffman, 1984; Maccoby, 1980; Radin, 1986). For female cognitive development, the data indicate that the presence of the father is one of the determinants of a daughter's proficiency in mathematics (Goldstein, 1982; Rosenberg \& SuttonSmith, 1966).

Previous research on the effects of maternal employment on children's cognitive development has underlined the need to examine moderating variables such as gender of the child and whether or not the mother

A revised version of a paper submitted to the Journal in March 1992. Work was supported by the University of Michigan School of Social Work. Authors are at the School of Social Work, University of Michigan, Ann Arbor. 
is employed full-time or part-time (Hoffman, 1989). Studies conducted within such subgroups, however, have not presented a consistent pattern of findings. Many have been unable to show any differences with respect to cognitive development between children whose mothers are employed and children whose mothers are unemployed (Armistead, Wierson, \& Forehand, 1990; Gottfried et al., 1988; Heynes, 1982; Heynes \& Catsambis, 1985). Some have shown more positive outcomes for children (Bronfenbrenner \& Crouter, 1982; Hoffman, 1984, 1989; Hutner, 1972; Zaslow et al., 1991) and especially for sons (Bogenschneider, 1990) with maternal part-time employment than with full-time employment or no employment. Maternal employment that exceeds 40 hours a week has been found to be related to more negative developmental outcomes (Gottfried et al., 1988; Owen \& Cox, 1988).

Based on the above theories and the empirical data, the following hypotheses were generated about adolescents' academic achievement and expectations in white, middle-class, intact families.

1. Adolescent children of mothers who were employed part-time, as compared to full-time or no employment, when the teenagers were 3-5 years old and 7-9 years old would $a$ ) be more likely to report higher grades and $b$ ) be more likely to report greater expectations of attending a graduate or professional school.

2. Adolescents who experienced large amounts of father involvement in child rearing when they were 3-5 and 7-9 years old as compared to teens who experienced less father involvement would also $a$ ) be more likely to report higher grades and $b$ ) be more likely to report greater expectations of attending a graduate or professional school.

Gender of the child was explored as an influence on the relationship between child outcomes and the parent variables investigated. Also explored were the interaction effects of different amounts of paternal involvement and maternal employment.

\section{METHOD}

In 1977 , a study was designed by Radin (1981a) and colleagues to examine antecedents and consequences of high fatherinvolvement in intact, white, middle-class families of preschool children aged 3-5 years. Interview data were collected on 59 families. Based on a Paternal Involvement in Child Care Index (PICCI) the sample of families was divided into thirds reflecting low (mother as primary caregiver), medium (intermediate), and high (father as primary caregiver) father participation. The study was repeated in 1981 (time 2) when the children were 7-9 years old with 47 families who were located, agreed to participate, and were still intact (Radin \& Goldsmith, 1985).

In 1988 (time 3), a second follow-up investigation was undertaken with the 32 remaining intact families who agreed to participate. The initial data analysis from this 11-year follow-up focused on the extent to which the now-teenage children's expectations for gender roles in career and family contexts were altered when fathers played a large role in child rearing in prior years (Williams, Radin, \& Allegro, 1992). The focus of the investigation (described below) was the academic achievement and expectations of the adolescents.

Two dependent variables based on data collected from the adolescents in the time-3 study were employed. The first pertained to the adolescents' self-reported grades and was scored as follows: $A=1, A-=2, B+=3$, $B=4, B-=5, I=6, C=7, C-=8$, and $D=9$. The mean was 2.91. A student $t$-test indicated that there were no significant differences with respect to gender across the self-reported grades. The second dependent variable was the response to the query "How likely is it you'll attend graduate or professional school after college?" The responses were scored as follows: definitely won' $t=1$; probably won' $t=2$; probably will $=3$; and definitely will $=4$. The mean was 2.91 . Again, student $t$-tests indicated there were no significant gender differences across re- 
sponses for either variable. The correlation between self-reported grades and the expectation of attending a graduate or professional school was not significant.

There were five independent variables in the investigation. The first one was the gender of the teenager. The second was the trichotomized PICCI score obtained in the original 1977 (time 1) study. The third independent variable was the trichotomized PICCI scores of the time 2 study. The fourth independent variable was the amount of maternal employment outside the home at time 1 when the children were 3-5 years old. It was scored as follows: $1=$ unemployed, $2=$ mainly part-time, and $3=$ mainly fulltime. The questionnaire did not inquire about the specific number of hours the mothers worked. The fifth pertained to the number of maternal employment hours at time 2 when the children were 7-9 years old. This variable was scored as follows: $1=$ unemployed ( $0-10$ hours employment), $2=$ parttime (11-34 hours), 3 = full-time (35-40 hours), and $4=$ overtime $(41+$ hours). By design none of the mothers in the motheras-primary-caregiver group worked fulltime at time 1 .
In TABLE 1 are presented data for the father-involvement subgroups at time 1 and time 2 by gender of child and maternal employment groups at these times. Chi-square tests indicated that gender of child was unrelated to amount of child-rearing involvement by fathers and amount of employment by mothers at time 1 and time 2 .

To determine if the extraneous variable of amount of education affected paternal involvement or maternal employment, Pearson's product moment correlations were computed between each of those variables and the relevant parent's education. The correlation for the members of the 11-year follow-up sample between father's education and the PICCI score was not significant at time 1 but was significant at time $2(r=$ $.36, p<.05)$. The mean was almost a graduate degree. Therefore, analyses of covariance were computed for both dependent variables with father involvement as the independent variable and fathers' education as the covariant; the results obtained were not significant. There were no significant correlations for the mothers' education and hours of employment either at time 1 or at time 2 in the 11-year follow-up sample.

Table 1

TIME 1 AND TIME 2 PARENTING GROUPS BY MATERNAL EMPLOYMENT GROUPS AND GENDER

\begin{tabular}{|c|c|c|c|c|c|c|}
\hline \multirow[b]{2}{*}{$\begin{array}{l}\text { MATERNAL } \\
\text { EMPLOYMENT } \\
\text { GROUPS }\end{array}$} & \multicolumn{3}{|c|}{ TIME 1 FATHER INVOLVEMENT GROUPS } & \multicolumn{3}{|c|}{ TIME 2 FATHER INVOLVEMENT GROUPS } \\
\hline & $\begin{array}{c}\text { FATHER } \\
\text { PRIMARY } \\
(N=12)\end{array}$ & $\begin{array}{c}\text { INTER- } \\
\text { MEDIATE } \\
(N=10)\end{array}$ & $\begin{array}{l}\text { MOTHER } \\
\text { PRIMARY } \\
(N=10)\end{array}$ & $\begin{array}{l}\text { FATHER } \\
\text { PRIMARY } \\
(N=4)\end{array}$ & $\begin{array}{c}\text { INTER- } \\
\text { MEDIATE } \\
(N=11)\end{array}$ & $\begin{array}{c}\text { MOTHER } \\
\text { PRIMARY } \\
(N=17)\end{array}$ \\
\hline $\begin{array}{l}\text { Unemployede } \\
\text { Males } \\
\text { Females }\end{array}$ & $\begin{array}{l}1 \\
1\end{array}$ & $\begin{array}{l}1 \\
0\end{array}$ & $\begin{array}{l}1 \\
5\end{array}$ & $\begin{array}{l}0 \\
0\end{array}$ & $\begin{array}{l}1 \\
0\end{array}$ & $\begin{array}{l}6 \\
6\end{array}$ \\
\hline $\begin{array}{l}\text { Part-Timeb } \\
\text { Males } \\
\text { Females }\end{array}$ & $\begin{array}{l}2 \\
1\end{array}$ & $\begin{array}{l}3 \\
1\end{array}$ & $\begin{array}{l}2 \\
2\end{array}$ & $\begin{array}{l}0 \\
0\end{array}$ & $\begin{array}{l}0 \\
0\end{array}$ & 1 \\
\hline $\begin{array}{l}\text { Full-Time } \\
\text { Males } \\
\text { Females } \\
\text { Overtimed }^{\circ}\end{array}$ & $\begin{array}{l}5 \\
2\end{array}$ & $\begin{array}{l}3 \\
2\end{array}$ & $\begin{array}{l}0 \\
0 \\
0\end{array}$ & $\begin{array}{l}1 \\
1 \\
. \\
\end{array}$ & 2 & $\begin{array}{l}1 \\
0\end{array}$ \\
\hline $\begin{array}{l}\text { Males } \\
\text { Females }\end{array}$ & & & & $\begin{array}{l}0 \\
2\end{array}$ & $\begin{array}{l}5 \\
0\end{array}$ & $\begin{array}{l}1 \\
1\end{array}$ \\
\hline
\end{tabular}

Note. Time $1=3-5$ years old; time $2=7-9$ years old.

- At time 2 employed 0-10 hrs pw.

- At time 2 employed 11-34 hrs pw.

c At time 2 employed 35-40 hrs pw.

d At time 2 employed 41 or more hrs pw. 
Pearson's product moment correlations were also computed to determine if the adolescents' reported grades and their expectations for higher education were related to the amount of their parents' education. The results were not significant.

Reasons for maternal employment, i.e., had to work, wanted to work, or both, at time 1 (information regarding reasons for maternal employment was not obtained at time 2), number of children at time 1 and at time 2, and birth order of the target child were examined by one-way ANOVAs with paired comparisons to determine if there were any differences across father involvement and maternal employment groups. The results for number of children $(M=1.8)$ and reasons for employment (had to work = $14 \%$, wanted to work $=23 \%$, and both $=$ $63 \%$ ) were not significant across fatherinvolvement groups and across maternalemployment groups. The results for birth order were not significant across maternalemployment groups at time 1 and time 2 and across father-involvement groups at time 2. However, there was a significant overall $F$ for birth order across father groups, $F(2,29)=3.94, p<.05$. There was also one significant subgroup comparison, $F(3,10)=$ $4.20, p<.05$. Children in the intermediate parenting group were more likely to be firstborn $(M=1.2)$ than were those in the mother-primary caregiver group $(M=1.7)$.
Analyses of covariance were computed for both dependent variables, with father involvement as the independent variable and birth order as the covariant; the results were not significant. The correlations between birth order and the two dependent variables were also not significant.

\section{RESULTS}

One-way ANOVAs with paired comparisons were computed for both dependent variables, with mothers' employment at time 1 and at time 2 as the independent variables. This analysis was completed for the group as a whole and then for each gender subgroup. The entire set of analyses was then repeated using father involvement as the independent variable. Significant results are summarized in TABLE 2 .

These indicate that children of mothers with part-time employment when the youngsters were 3-5 years old had higher overall grades than peers with mothers who worked full-time. Furthermore, grades were significantly lower for children of mothers working overtime when the youngsters were 7-9 years old than for peers with nonworking mothers. As can be seen in TABLE 2, sons were more likely to expect to attend graduate school if their mothers were employed part-time than if their mothers were unemployed when the boys were 3-5 years old.

Two-way ANOVAs were performed for

Table 2

ONE-WAY ANOVAS: SIGNIFICANT RELATIONSHIPS BETWEEN DEPENDENT AND INDEPENDENT VARIABLES

\begin{tabular}{|c|c|c|c|c|c|c|}
\hline \multirow[b]{2}{*}{ GROUP } & \multicolumn{2}{|c|}{ VARIABLES } & \multirow[b]{2}{*}{$F$} & \multirow{2}{*}{$\begin{array}{c}\text { PAIRS WITH SIG. } \\
\text { DIFFS }\end{array}$} & \multirow[b]{2}{*}{$M$} & \multirow[b]{2}{*}{$F$} \\
\hline & DEPENDENT & INDEPENDENT & & & & \\
\hline $\begin{array}{l}\text { Time } 1 \\
\text { Total group } \\
\text { Males }\end{array}$ & Grades" & Maternal employ & $\begin{array}{l}2.95^{*} \\
2.38\end{array}$ & $\begin{array}{l}\text { Part-time/Full-time } \\
\text { Part-time/Full-time }\end{array}$ & $\begin{array}{l}2.18 / 3.58 \\
2.00 / 3.50\end{array}$ & $\begin{array}{l}5.90^{* *} \\
4.72^{* *}\end{array}$ \\
\hline Time 2 & & & & & & \\
\hline $\begin{array}{l}\text { Total group } \\
\text { Females }\end{array}$ & & & $\begin{array}{l}2.13 \\
4.26^{* *}\end{array}$ & $\begin{array}{l}\text { Unemployed/Overtime } \\
\text { Unemployed/Overtime } \\
\text { Part-time/Overtime }\end{array}$ & $\begin{array}{l}2.31 / 3.78 \\
2.17 / 5.00 \\
2.00 / 5.00\end{array}$ & $\begin{array}{r}5.92^{* * *} \\
11.82^{* * *} \\
4.97^{* * *}\end{array}$ \\
\hline Time 1 & $\begin{array}{l}\text { Higher ed. } \\
\text { expectations }\end{array}$ & Maternal employ & & & & \\
\hline Males & & & $3.27^{*}$ & Part-time/Unemployed & $3.00 / 2.33$ & $6.46^{* \star}$ \\
\hline
\end{tabular}


both dependent variables, with mothers' employment and father involvement as the independent variables to determine if there were any interaction effects. These analyses were performed separately for the time-1 data when the children were preschoolers and for the time-2 data when the children were 7-9 years old. There was a significant main effect for mother's employment, $F(1,32)=3.73, p<.05$, when the expectation of attending graduate school was the dependent variable. Adolescents whose mothers were employed part-time when they were preschoolers had the highest mean (3.20). The group with the lowest mean (2.75) was for mothers employed full-time. Intermediate, with a mean of 2.78 , was the group of unemployed mothers.

There was also a significant interaction between father's involvement and mother's employment, $F(3,31)=4.68, p<.01$, when the children were 3-5 years old. Adolescents who as preschoolers were in the fatherprimary caregiver group and whose mothers were employed part-time had higher scores $(M=3.33$, "probably will attend graduate school") than did the other seven cells with combinations of father-involvement groups and mother-employment groups (one cell was empty). The lowest mean (2.00, "probably won't attend graduate school") was found in the two unemployedmother groups, one where fathers were primary caregivers and the other where fathers were moderately involved in child rearing.

\section{DISCUSSION}

This study examined the extent to which teenagers' self-reported grades and their expectations for graduating from a four-year college and going on to attend a graduate or professional school were affected by growing up in families where mothers were employed, traditional parental roles were partly reversed, or where both conditions prevailed. Because the sample was small and pertained only to white middle-class families, these findings can only suggest trends and should not be generalized beyond a white middle-class population.

The first hypothesis was supported. Mothers who were employed part-time when the adolescents were 3-5 years old and 7-9 years old were more likely than were mothers employed full-time or unemployed to have children who reported higher grades. For the group as a whole there was evidence that adolescents whose mothers worked 11-34 hours a week when they were 3-5 years old were doing better academically than adolescents whose mothers worked 35 hours or more. Particularly detrimental was overtime work. Perhaps the beneficial effects for mothers of interacting with adults in a challenging job context are overcome when they work long hours. Under these circumstances, mothers may have relatively little time or enthusiasm for oneon-one interaction with their children.

The optimum age for experiencing benefits from part-time maternal employment differed with the gender of the adolescent. Sons whose mothers were employed parttime when they were preschoolers or younger reported higher achievement than did their peers whose mothers worked fulltime. Daughters whose mothers worked parttime or were unemployed when they were 7-9 years old reported higher achievement in school than did the daughters of mothers who worked full-time or overtime. Possibly, preschool age boys are more active than preschool age girls and require more maternal attention to keep them engaged in constructive, mentally challenging activities. However, by age 7-9 these sons were more involved in peer activities and not damaged by a mother's full-time employment. School-age girls, on the other hand, may be at the stage when their femininity is emerging and may need a closer relationship with their mothers as a source of information, guidance, and modeling.

The hypothesis regarding an association between part-time maternal employment and the expectation of attending a graduate or professional school was also supported, but 
not as strongly. Teenagers with mothers who were employed part-time when they were preschoolers were more likely to see themselves as attending graduate or professional school than were the teenage children of mothers who were unemployed or who worked full-time. Sons whose mothers were employed part-time when the boys were preschoolers appeared to be particularly favored by this arrangement. Perhaps the adolescent children of mothers who were employed part-time when the teenagers were youngsters received the benefit of a mother with enough time to become involved in their schooling and also the benefit of a positive and powerful role-model engaged in the pursuit of a career.

The hypothesis that greater father involvement in child rearing when the adolescents were 3-5 or younger and 7-9 years old would be associated with higher selfreported grades was not supported. It may be that father involvement was a poor determinant of academic endeavors because the men who were very involved in child rearing almost invariably paid a cost in terms of career (Radin, 1981a). For example, although enjoying closer relationships with their children, the highly involved men offered comments such as "I have less time to practice" (said by a musician) and "I can't publish as much as I used to" (said by an academic). Although the average amount of education of the men in this fatherprimary caregiving group at time 1 was a B.A. degree and at time 2 almost a graduate degree, their own lives were not exemplars of achievment in professional status. The knowledge that their fathers had put careers on the back burner may have had a negative impact on the adolescents' academic performance and expectations.

There was evidence, however, that during the preschool years increased father participation combined with mothers' parttime work contributed to the likelihood that the teenagers would expect to attend a graduate or professional school. Perhaps children from such families are socialized at a very early age to wish to educate themselves for professional roles in which they can be free to fulfill their occupational aspirations and also determine the life-style they wish to adopt.

The major finding of this study was that mother's employment was a much more powerful long-term predictor of children's academic performance and future educational plans than was amount of father involvement. The paternal message to get good grades and an advanced degree may have been counterbalanced by the fact that the involved fathers had put their careers on hold. In contrast, the mothers who were participating in the work force while still spending a considerable amount of time at home with the children were sending the clear message to have a career.

These findings can have important implications for social policy. Employers should be encouraged to offer alternative employment arrangements, such as job sharing, home-based work sites, and flexible work hours. Such arrangements would permit mothers of children under nine years of age to spend more time at home with their youngsters while at the same time continuing their careers. Health-care packages for part-time employees should allow some mothers, who might otherwise have to work full-time in order to obtain these benefits, the opportunity to work less than 35 hours a week. Finally, child-care facilities located at the workplace would provide those mothers who must work full-time out of economic necessity more access to their children.

As previously stated, this study pertained only to white, middle-class, intact families, and the results should not be generalized beyond that population. However, in view of the large percentage of working mothers with young children from all racial backgrounds, and of society's greater acceptance of fathers who play a large role in child rearing, the results warrant reporting. Future longitudinal studies that address other racial and class groups would be useful ad- 
ditions to the body of knowledge that is now being accumulated.

\section{REFERENCES}

Armistead, L., Wierson, M., \& Forehand, R. (1990). Adolescents and maternal employment: Is it harmful for a young adolescent to have an employed mother? Journal of Early Adolescence, 10, 260278.

Bogenschneider, K.P. (1990). Maternal employment and academic achievement: Mediating, moderating and developmental influences. Dissertation $A b$ stracts International, 51(4), 2082B.

Bronfenbrenner, U., \& Crouter, A.C. (1982). Work and family through time and space. In S.B. Kamerman \& C.D. Hayes (Eds.), Families that work: Children in a changing world (pp. 39-83). Washington, DC: National Academy Press.

Eccles, J.S., \& Hoffman, L.W. (1984). Sex roles, socialization, and occupational behaviors. In H.W. Stevenson \& A.E. Siegel (Eds.), Child development research and social policy (pp. 367-420). Chicago: University of Chicago Press.

Goldstein, H.S. (1982). Fathers' absence and cognitive development of 12-17 year olds. Psychological Reports, 51, 843-848.

Gottfried, A.E., Gottfried, A.W., \& Bathurst, K. (1988). Maternal employment, family environment, and children's development: Infancy through the school years. In A.E. Gottfried \& A.W. Gottfried (Eds.), Maternal employment and children's development: Longitudinal research (pp. 11-58). New York: Plenum.

Heynes, B. (1982). The influence of parents' work on children's school achievement. In S.B. Kamerman \& C.D. Hayes (Eds.), Families that work: Children in a changing world (pp. 229-267). Washington, DC: National Academy Press.

Heynes, B., \& Catsambis, S. (1985). Working mothers and the achievement of children: A critique. Sociology of Education, 18, 308-321.

Hoffman, L.W. (1984). Work, family, and the socialization of the child. In R.D. Parke (Ed.), The family: Review of child development research (Vol. 7 , pp. 223-282). Chicago: University of Chicago Press.

Hoffman, L.W. (1989). Effects of maternal employment in the two-parent family. American Psychologist, 44, 283-291.
Hutner, F.C. (1972). Mother's education and working: Effect on the school child. Journal of Psychology, 82, 27-37.

Jordan, B.J., Radin, N., \& Epstein, A. (1975). Paternal behavior and the intellectual functioning in preschool boys and girls. Developmental Psychology, 11, 407-408.

Maccoby, E.E. (1980). Social development, psychological growth, and parent-child relations. New York: Harcourt Brace Jovanovich.

Owen, M.T., \& Cox, M.J. (1988). Maternal employment and the transition to parenthood. In A.E. Gottfried (Eds.), Maternal employment and children's development: Longitudinal research (pp. 85-119). New York: Plenum Press.

Radin, N. (1972). Father-child interaction and the intellectual functioning of four-year-old boys. Developmental Psychology, 6, 353-361.

Radin, N. (1981a). Childrearing fathers in intact families, I: Some antecedents and consequences. MerrillPalmer Quarterly, 27, 398-514.

Radin, N. (1981b). The role of the father in cognitive, academic and intellectual development. In M.E. Lamb (Ed.), The role of the father in child development (pp. 379-427). New York: John Wiley.

Radin, N. (1986). The influence of fathers on their sons and daughters. Social Work in Education, 8, 77-91.

Radin, N., \& Goldsmith, R. (1985). Caregiving fathers of preschoolers: Four years later. MerrillPalmer Quarterly, 28, 111-136.

Radin, N., \& Russell, G. (1983). Increased paternal participation and childhood outcomes. In M.E. Lamb \& A. Sagi (Eds.), Fatherhood and family policy (pp. 191-218). Hillsdale, NJ: Lawrence Erlbaum.

Rosenberg, B.G., \& Sutton-Smith, B. (1966). Sibling association, family size and cognitive abilities. Journal of Genetic Psychology, 107, 271-279.

Williams, E., Radin, N., \& Allegro, T. (1992). Sexrole attitudes of adolescents reared primarily by their fathers: An 11-year follow-up. Merrill-Palmer Quarterly, 38, 457-476.

Zaslow, M.J., Rabinovich, B.A., \& Suwalsky, J.T. (1991). From maternal employment to child outcomes: Preexisting group differences and moderating variables. In J.V. Lemer \& N.L. Galambos (Eds.), Employed mothers and their children (pp. 237-282). New York: Garland. 